\title{
Kirjallisuutta
}

\section{Vaikuttavuuden problematiikka koulutuksessa}

Tapio Vaherva: Koulutuksen vaikuttavuus. Käsiteanalyyttistä tarkastelua ja viitekehyksen hahmottelua. Jyväskylän yliopiston kasvatustieteen laitoksen yulkaisuja A 1/ 1983.

Torsten Husèn, tunnettu ruotsalainen kasvatustieteilija ja professori emeritus, joka vanhemmiten on tullut kriittisemmäksi ja epäilevämmäksi koulutuksen mahdollisuuksiin ja vaikutuksiin nyky-yhteiskunnassa, kertoo muistelmateoksessaan An Incurable Academic (1983) miten hänestä tuntui, että koulun kritikoiminen oli kuin "pyhään lehmään kajoamista". Kun syksyllä 1978 järjestettiin Tukholmassa symposium teemana Koulu kriisissä, oli suhtautuminen siihen varsin nuivaa: opettajajärjestöt osoittivat vähäistä kiinnostusta asiaan; järjestäjiä moitittiin siitä, että he eivät aihetta ja ohjelmaa suunnitellessaan ottaneet yhteyttä koulualan ammatillisiin järjestöihin, joukkoviestimet eivät maininneet sanallakaan koko symposiumista; ja koululaitoksen hallintovirkamiehet valittelivat, että koulusta käytävässä julkisessa keskustelussa vallitsevat kovin kielteiset asenteet.

Apulaisprofessori Tapio Vaherva, jonka viime vuonna ilmestynyttä tutkimusta koulutuksen vaikuttavuudesta jatkossa esitellään, tuntee nähtävästi hieman samoin onhan koulutuksen vaikutuksia tutkittaessa aina mukana myös kriittinen momentti kun hän teoksensa esipuheessa kirjoittaa: '’lukijalle saattaa muodostua
sellainen käsitys, että olen ot-
tanut 'pyhä asian' - koulu-
tuksen - tarkasteltavaksi sel-
laisesta näkökulmasta, joka
on arveluttava: hyötyä, te-
hokkuutta ja vaikutuksia
myös taloudelliselta kannalta
analysoiva. Olen ollut kuiten-
kin täysin tietoinen siitä, että
suurin osa koulutuksesta on
sellaista yhteiskunnallista toi-
mintaa, jonka 'kannattavuut-
ta' ei voi asettaa kyseenalai-
seksi taloudellisin perustein.
Toisaalta olen täysin vakuut-
tunut myös siitä, että koulu-
tusta pitää tarkastella kriitti-
sesti myös taloudellisia näkö-
kohtia painottaen."

Kasvatusta ja koulutusta käsittelevä evaluaatiotutkimus, johon koulutuksen vaikuttavuustutkimuskin luonnollisesti kuuluu, on, kuten evaluaatiotutkimus yleensäkin, arkaluontoista ja helposti kannanottoja herättävää. Vaikuttavuustutkimuksessa on kysymys erittäin monimutkaisesta edellytysten, syiden, seurausten ja vastatendenssien verkostosta, jonka tutkimus voi parhaimmillaankin vain likimääräisesti tavoittaa. Tutkimuksiin kohdistuu helposti myös ristiriitaisia ja epärealistisia odotuksia, joita kaikkia on mahdotonta ottaa huomioon. Jos evaluaation tulokset eivät sitten olekaan ennakko-odotusten mukaisia, on mappi ö todennäköisempi vaihtoehto kuin syiden perinpohjainen selvittäminen. Esim. yhdysvaltalaiset miljoonaprojektit, Project Talent. Head Start ja Follow Through sekä IEA:n kansainväliset koulusaavutustutki- mukset ovat vastaanotoltaan olleet lievästi ilmaisten ristiriitaisia.

Koulutuksen vaikuttavuuden empiirinen tutkiminen on itse ilmiön (koulutus) laajuuteen ja merkittävyyteen nähden ollut varsin vähäistä, ja tilanne on sama muuallakin kuin Suomessa. Erityisesti tämä pitää paikkansa aikuiskasvatuksesta ja työelämän koulutuksesta puhuttaessa. Yhdysvalloissakaan, jossa yritystason koulutuksella on vuosikymmenien perinteet ja tulosajattelu vakiintunutta ja pitkällevietyä, ei ole juuri päästy asiassa puusta pitkään. Arvostetussa ja paljon siteeratussa, jo vuonna 1970 ilmestyneessä, Campbell et al.: Managerial Behavior, Performance, and Effectiveness, kirjoittajat tiivistivät johtamiskoulutuksen osalta silloisen tilanteen seuraavasti: "The major question at this point concerns how long organizations will follow a policy that is best characterized as spending millions for training but not one penny for training evaluation."

Kun ei panosteta, on turha odotella tuloksiakaan. Niinpä tilanne on uudempienkin arvioiden mukaan paljolti samanlainen kaikessa työelämän koulutuksessa. Ja kun evaluaatiota on tehty, on se tavallisesti ollut koulutukseen osallistuneiden mielipiteiden kirjaamista, nk. "mutu" ja 'tyko'"-evaluaatiota ('musta tuntuu, että kyllä tästä jotain hyötyä on" ja 'tykkäsin kovasti"'), joka yleensä tuottaa varsin positiiviset arviot. Sen sijaan oppimisen tai peräti 
koulutuksen ulkopuolisten kriteerien, esim. työsuorituksen muutosten arviointi, käyttäminen on evaluaatiossa jäänyt varsin harvinaiseksi.

Empiirisen vaikuttavuustutkimuksen vähäisyydestä huolimatta on evaluaatioproblematiikkaan liittyvää teoreettista ainesta löydettävissä yhteiskunta- ja käyttäytymistieteellisestä kirjallisuudesta kuitenkin varsin runsaasti. Tätä materiaalia käy kirjoittaja po. tutkimuksessa perusteellisesti hyödyntämään.

Vaherva lähestyy koulutuksen vaikuttavuutta monitieteisesti eri näkökulmista: kasvatustieteellisestä, perinteisen evaluaatiokäsitteen pohjalta; kasvatussosiologisesta, funktionalistisesta ja konfliktiteoreettisesta positiosta käsin; ja koulutuksen taloustieteellisestä, lähinnä inhimillisen pääoman teoriasta käsin.

Perinteinen kasvatustieteellinen evaluaatio on kohdistunut yleensä välittömien oppimistulosten arvioimiseen. Koulukokeet, opettajan tarkkailu ja havainnointi tunneilla ja erilaiset koulusaavutustestit ovat sitä mitä evaluaatiolla tavallisesti ymmärretään. Laajimmillaan se on ollut opetussuunnitelmatasoisessa arvioinnissa mutta rajoittunut kuitenkin tavallisestî koulutusta organisoivan laitoksen puitteisiin. Vanha hokema "ei koulua vaan elämää varten" - on koulutuksen vaikutuksia arvioitaessa päässyt unohtumaan. Aikuiskasvatuksessa ja työelämän koulutuksessa erityisesti on tämä periaate kuitenkin keskeinen. Vaherva laajentaa ja täydentää evaluaation käsitettä tähän suuntaan painottamalla aikaperspektiivin merkitystä ottamalla mukaan mm. seurannan ja viivästetyn arvioinnin käsitteet.

Koulutuksen vaikutusten voidaan ajatella muodostavan eräänlaisen peräkkäisten vaiheiden ketjun. Koulutus aiheuttaa koulutettavassa reaktioita; reaktioita seuraa oppiminen; oppiminen muuttaa työkäyttäytymistä; työkäyttäytymisen muutosta seuraa organisaation muutokset; ja viimeksi seuraa perimmäisen hyödyn (mitä se sitten kulloinkin onkin) saavuttamisessa tapahtuvat muutokset. Ketju voi katketa missä vaiheessa tahansa, ja arvioinnin tehtävänä on seurata etenevätkö vaikutukset katkeamatta. Mitä pidemmälle koulutusvaikutusten ketjussa edetään sitä kauempana myös ajallisesti ollaan varsinaisesta koulutustapahtumasta. Ketjun ensimmäisten lenkkien, reaktioiden ja oppimisen ollessa kyseessä, voidaan puhua myös koulutuksen lyhyen aikavälin tavoitteista, koulutustuotoksista. Ketjun seuraavat lenkit vastaavat koulutuksen pitkän tähtäimen tavoitteita, ja ehkä vasta tällöin on perusteltua puhua koulutusvaikutuksista. Koulutustuotoksien arvioinnilla saadaan nopeasti välitöntä tietoa, jota käytännön koulutustyössä tarvitaan, mutta koulutuksen todellisten vaikutusten selvittämiseksi on otettava mukaan myös koulutuksen ulkopuolisia kriteereitä, joissa vaikutusten oletetaan tai tarkoitetaan ilmenevän koulutuksen jälkeen. Tässä on viivästetyn arvioinnin idea.

Viivästetyn arvioinnin pätevä ja luotettava toteuttaminen on kuitenkin sekä käytännöllisistä että tutkimusteknisistä ja -metodisista syistä varsin vaativa tehtävä. Se edellyttää useimmiten klassista koejärjestelyä jäljitteleviä tutkimusasetelmia koe- ja vertailuryhmineen ja useita mittauskertoja. Muutoksen mittaaminen vaatii mittareilta erityistä herkkyyttä, reliaabeliutta ja validiutta sekä myös muiden kuin koulutuksen muutosvaikutuksen huomioimista kriteerimuuttujassa.

Kun kasvatustieteellisessä evaluaatiossa tarkastelun painopiste on yleensä oppivassa yksilössä niin kasvatussosiologinen evaluaatio siirtää sen organisaatioiden ja järjestelmien, usein koko yhteiskunnan tasolle. Keskeiseen ase- maan nousevat tällöin kysymykset koulutuksen roolista ja tehtävistä yhteiskunnassa. Onkin nähty, että koulutuksen olemassaolo yhteiskunnallisena instituutiona perustuu juuri sen positiivisiin vaikutuksiin sekä yksilöön että laajemmin koko yhteiskuntaan osajärjestelmineen - ellei näin olisi, koulutusinstituutio häviäisi tarpeettomana pois.

Kasvatussosiologiselle lähestymistavalle on niin ikään ominaista yhteiskunnan rakenteellisten seikkojen korostaminen. Sekä funktionalistinen (tai konsensusteoreettinen) että konfliktiteoreettinen koulukunta edustavat tässä kohden yhdenmukaista näkemystä. Mutta kun funktionalistinen teoria lähtee siitä, että yhteiskunta eri osajärjestelmineen pyrkii tasapainoon ja harmoniaan yhteisten arvojen ja normien ohjaamana, niin konfliktiteoria painottaa, että yhteiskunnassa on erilaisten, jopa vastakkaisten tavoitteiden pohjalta toimivia eturyhmittymiä, eikä yhteisistä arvoista ja tavoitteista näin ollen voida puhua. Funktionalistinen teoria katsoo, että koulutuksen tehtävänä on sosiaalista liikkuvuutta edistämällä saada. yhteiskunnan kyky- ja tehtävärakenne vastaamaan toisiaan ja yleensäkin tuottaa kykeneviä ja halukkaita yksilöitä yhteiskunnassa tarvittaviin eri tehtäviin. Konfliktiteoria sen sijaan korostaa, että myös kasvatuksen ja koulutuksen alueella on ensisijainen kysymys vallasta l. siitä kuka saa määrätä yhteiskunnalliset tavoitteet ja mitä päämääriä ne palvelevat. Näitä päämääriä palvelemaan asettavat valtaa pitävät sitten myös kasvatuksen.

Rakenteellisen selitysperusteen kritiikistä on syntynyt viime vuosikymmenellä näkyväksi noussut nk. tulkinnallisen sosiologian suuntaus, joka ammentaa perusteitaan monesta lähteestä: fenomenologiasta, etnometodologiasta ja symbolisesta interaktionis- 
mista. Tulkinnallinen sosiologia väittää, että rakenteellista selitysperustaa korostava suuntaus ei huomioi riittävästi ihmisen aktiivisuutta, kokemuksia, tilanteenmäärittelyjä ja tietoista toimintaa - yleensä merkityssuhteiden pohjalta konstituoitunutta inhimillistä käyttäytymistä; ihminen on sille liiaksi vain vastaanottava ja reagoiva osapuoli, rakenteen determinoima. Tulkinnallinen lähestymistapa korostaa, että myös kasvatuksen ilmiöitä tutkittaessa tulisi selitysperusteet rakentaa toimivan yksilön "elämismaailmasta", hänen omasta merkitysja tulkintahorisointistaan käsin.

Koulutuksen taloustieteellisestä tutkimusperinteestä Vaherva ottaa relevanttina mukaan inhimillisen pääoman teorian. Inhimillisen pääoman teorian pohjalta voidaan koulutuksen vaikutuksia analysoida lähinnä kolmella tasolla: mikrotasolla, jolloin analysoidaan yksilön näkökulmasta sitä, miten koulutusinvestointi erilaisten vaihtoehtojen ollessa kyseessä tuottaa yksilölle (tavallisesti taloudellista) hyötyä; mesotasolla, jolloin analyysiyksikkönä on yrityksen tai organisaation taso ja selvitetään miten yrityksen koulutukseen käyttämät panostukset edistävät sen varsinaista tavoitetta; ja makrotasolla, jolloin selvitetään koko yhteiskunnan tasolla ilmeneviä koulutuksen vaikutuksia esim. bruttokansantuotteen kasvuun.
Taloustieteellinen lähestymistapa soveltuukin mielestäni parhaiten juurri (taloudellista tulosta tavoittelevien) yritys- ja organisaatiotasoiseen tarkasteluun. Näin erityisesti sen vuoksi, että sekä yksilön että yhteiskunnan kannalta katsoen koulutuksella on monia sellaisia (taloustieteellisessä mielessä kulutuksen luonteisia) vaikutuksia, joiden rahamääräistä tai yleensä taloudellista arvoa on mahdotonta, erittäin vaikeaa tai tarpeetonta arvioida, ja näin ollen pelkästään taloudellisesti tarkastellen tulisi koulutuksen kustannukset yliarvioiduksi ja hyödyt aliarvioiduksi. Sen sijaan yritystasolla olisi perusteltua pyrkiä koulutuksen evaluaatioon myös taloudellisin termein.

Kaiken kaikkiaan voidaan todeta, että inhimillisen pääoman teoriaan kohdistuneesta kritiikistä huolimatta sillä on edelleenkin merkitystä, ja erityisesti koulutussuunnittelun alueella nk. kustannus-hyöty -analyysi näyttäisi tarjoavan sovelluskelpoisia ratkaisuja. Niinpä evaluaatiotutkimuskaan voi tuskin kokonaan hylätä tätä koulutuksen taloudellisiin vaikutuksiin painottuvaa tarkastelutapaa.

Tutkimuksensa lopuksi Vaherva yhdistelee näistä aineksista eräänlaisen moniulotteisen hypoteettisen mallin koulutuksen vaikuttavuudesta. Arvioinnin kohteet voivat vaihdella formaalin koulujärjestelmän antaman koulutuksen ja aikuiskasvatuksen eri alueiden välillä; tieteellinen ja käsitteellinen viitekehys saadaan kasvatustieteellisestä evaluaatiosta, kasvatussosiologiasta ja koulutuksen taloustieteestä; tarkastelutaso voi olla yksilössä, organisaatiossa tai yhteiskunnassa tai näiden yhdistelmä; arvioinnin aikaperspektiivi voi vaihdella välittömistä tuloksista jopa sukupolvien ylitse; arviointi voi olla luonteeltaan diagnostista, formatiivista, summatiivista ja ultimatiivista ja kohdistua resursseihin, prosesseihin, tuotoksiin ja lopullisiin tuloksiin. Nämä kaikki ainekset ja ulottuvuudet voivat ainakin periaatteessa olla mukana myös samassa vaikutusanalyysissä, mutta käytännön tutkimustyössä lienee tarkoituksenmukaista rajata vain osa aineksista yksittäiseen tutkimukseen, muuten työ laajenee pois hallinnasta ja eklektisyyden vaara teoreettisen taustan osalta käy ilmeiseksi.

Vaherva on tällä tutkimuksellaan tehnyt tärkeän päänavauksen ja hyvää käsitteellistä pohjatyötä koulutuksen vaikuttavuuden empiiristä tutkimusta ajatellen. Vaikuttavuustutkimus on ajankohtainen ja laajaa kiinnostusta viimeaikoina herättänyt tutkimusalue, jota selviteltäessä joudutaan puuttumaan myös kansliapäällikkö Nummisen peräämiin "tosiolevaisiin kasvatuksen ja koulutuksen ongelmiin"'.

Rainer Aaltonen 